\title{
ELASMOBRANCH DIVERSITY OF KALIMANTAN WATERS
}

\author{
Fahmi and M.Adrim \\ Research Centre for Oceanography, Indonesia Institute of Sciences \\ Jl. Pasir Putih I, Ancol Timur, Jakarta Utara, Indonesia. \\ e-mail:fahmi_lipi@yahoo.com
}

\begin{abstract}
A total of 2,310 individuals of elasmobranch fishes consisting of 60 species from 13 families were recorded from survey trips in Kalimantan waters. Six fish landing sites and markets in four provinces of Kalimantan were visited from September 2005 to November 2006. Some new records, endemic and new species were gathered during the surveys. Rays of Dasyatid family were the most common elasmobranch species occurring in this area. Himantura gerrardi, H. uarnak and H. uarnacoides (Dasyatidae) were the most common rays, whereas Chiloscyllium punctatum (Hemiscyllidae), Hemigaleus microstoma (Hemigaleidae), Carcharhinus amblyrhynchoides and $C$. dussumieri (Carcharhinidae) were the most common sharks recorded during this study. Some endemic and rare species were also recorded including Himantura lobistoma, H. pastinacoides, Pastinachus solocirostris (Dasyatidae) and Glyphis sp. (Carcharhinidae).
\end{abstract}

Keyword: Elasmobranchii, Diversity, New records, Abundance, Rare, Endemic.

\section{INTRODUCTION}

The tropical Indo-West Pacific region is recognized to be the centre of chondrichthyan diversity in the world (Compagno, 1984a), and as a large area in this region, Indonesian waters are assumed to have a high diversity of cartilaginous fishes with different communities in the different areas. A study on elasmobranch diversity had been conducted from April 2001 to March 2006 in eastern Indonesia (covering Java, Bali, Nusa Tenggara and Papua), and at least 135 chondrichthyan species consisting of 78 sharks, 56 rays and three chimaeras were recorded from this region (White et al., 2006). The exact number of chondrichthyans in Indonesia is assured more than the recorded numbers regarding to the expansive archipelago and the uniqueness of physical seascape of Indonesia (White et al., 2006). On the other hand, Indonesia recognizes the elasmobranch fishery as one of its important resources. The total production of cartilaginous fishes in Indonesia was 121,750 tonnes in 2004 including 59,230 tonnes of sharks and 62,520 tonnes of rays. Indonesia has the highest annual total production of elasmobranchs in the world (Stevens et al., 2000; Bonfil, 2002; TRAFFIC, 2002), which is of concern due to global alarm about the status of shark and ray resources. Therefore, information on the exact number of chondrichthyans in this country and their stocks should be provided for basic information in implementing better management of sustainable biodiversity.

The objective of this study was to investigate species diversity, catch composition and distribution of sharks and rays in western Indonesia, especially in Kalimantan waters. The study result will be useful as critical base-line data for future stock assessments and shark fisheries management.

\section{MATERIALAND METHODS}

A study was conducted by elasmobranch research group from Research Centre for Oceanography LIPI from September 2005 to November 2006 in Kalimantan. Data were collected from six fish landings in four provinces (i.e; Pontianak and Mempawah at West Kalimantan, Sampit at Central Kalimantan, Muara Kintap at South Kalimantan, Balikpapan and Samarinda at East Kalimantan) (Fig. 1). Each site was visited in seven consecutive days. During visiting, all chondrichthyan species were recorded and each specimen was measured if possible. The number 


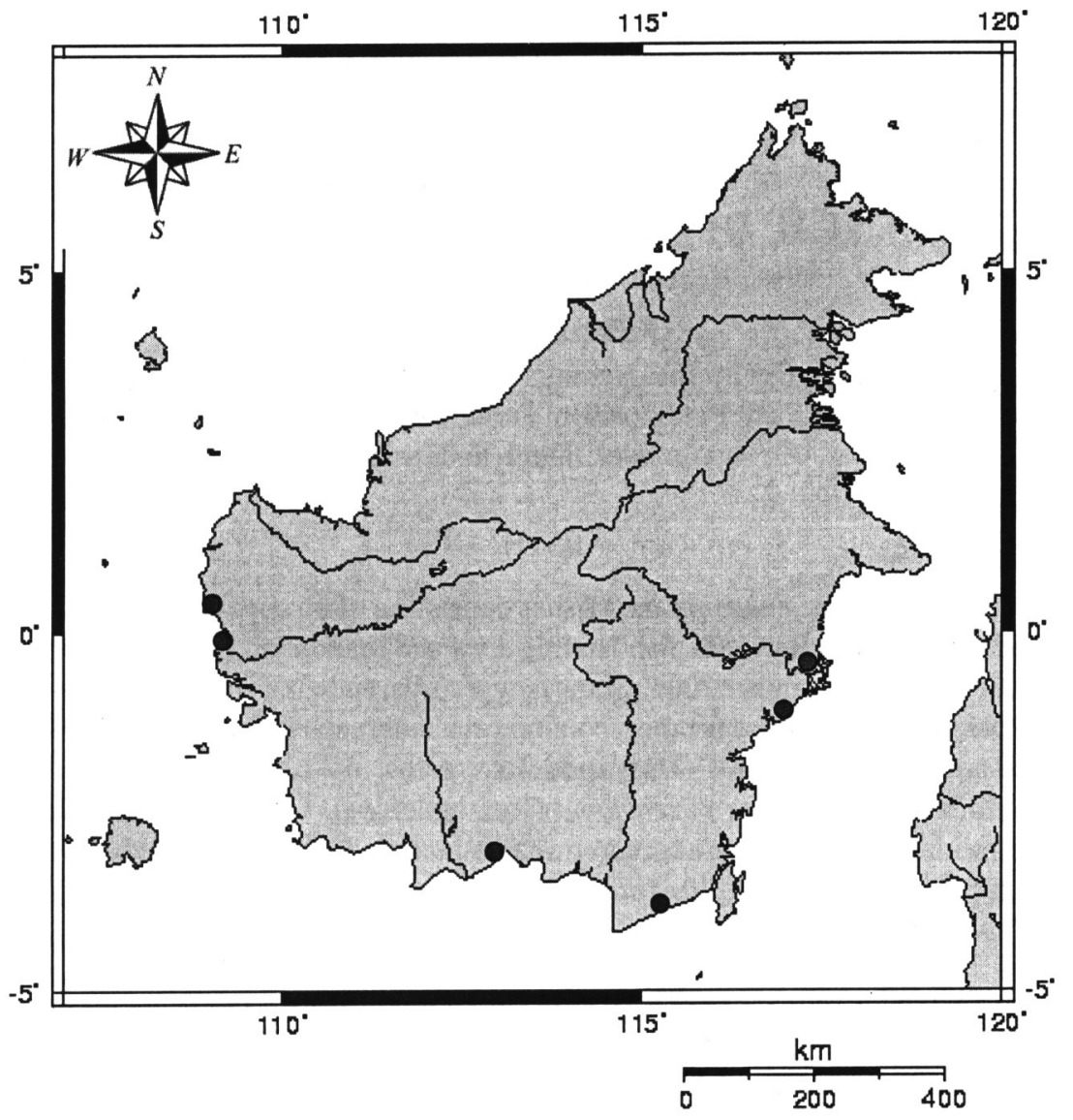

Figure 1. Map of Kalimantan Island showing six surveyed locations (•) at landing site.

of each species recorded represented the actual number of species present at each landing site during the study. Each species was identified following in Compagno (1998; 1999), Last and Compagno (2002), Last et al., (2005), and Manjaji and Last (2006). Undetermined species (for several reasons such as decomposition, mutilation, finned or unidentified) were identified to the level of genus and provided with a temporary name. Unidentified species thought to be new species were purchased and preserved with $10 \%$ formalin (when the size of the specimen made such collection practical). Larger specimens, which were impractical to collect in this way, were photographed using a digital camera (CANON A95) with five mega-pixel resolution for further identification and description.

In order to assess patterns among sites in chondrichthyan species diversity from each location, non-metric multidimensional scaling (MDS) analysis (PRIMER v.5.2.4) was used. This analysis has the ability to plot data in a "map" and puts samples that have high rank of similarity close each other, and it is easy to interpret by users (Clarke \& Warwick, 1994). Species compositions according to the presence and absent data of chondrichthyans landed in each location were analyzed using MDS. The Bray-Curtis index was used to obtain similarity ranks among locations to derive a similarity matrix for plotting MDS configuration plots. Species compositions from each site per occasion were compared using oneway analysis of similarities (ANOSIM). ANOSIM was used to test the significance of differences of species composition among sites (Clarke, 1993). Species diversity from each location was also measured using index of evenness (Smith and Wilson's index) (Krebs, 1999).

\section{RESULTS}

A total of 2,310 individuals, consisting of 60 species and 13 families were recorded from 12 landing sites during this study. This total consisted of 26 species of shark representing 5 families and 34 species of rays (including stingrays, eagle rays, 
devil rays, shark ray, shovelnose rays and guitar fishes) representing eight families (Table 1). Dasyatidae was the most common family recorded during the study in terms of the number of individuals and species, represented by 1,279 individuals and 18 species. Himantura gerrardi, $H$. uarnak and $H$. uarnacoides (Dasyatidae) were the most common species recording at all landing sites during the study. According to the species abundance, $D$. kuhlii and $H$. gerrardi were the most abundant rays that contributed about $15 \%$ each of the total abundance of chondrichthyans recording during the study. On the other hand, the common sharks recording during the study were Chiloscyllium punctatum
(Hemiscyllidae) and Hemigaleus microstoma (Hemigaleidae), Carcharhinus amblyrhynchoides and $C$. dussumieri (Carcharhinidae). These four species were recorded at least at four landing sites during the study. Regarding to their abundance, those four species contributed only less than 5\% of the total number of elasmobranchs recorded. Conversely, other shark species, Paragaleus teng $i$ (Hemigaleidae) and Scoliodon laticaudus (Carcharhinidae), contributed about 5\% and 9\% to the total number of elasmobranchs recorded, even though they were recorded from only one landing site. (Table 1).

A few species were known as having limited distributions either in Indo-Malay region in

Table 1. List of chondrichthyans from six fish landing sites in Kalimantan (Pont = Pontianak; Memp= Mempawah; MKtp = Muara Kintap; Samp = Sampit; Mang = Manggar; Samr = Samarinda $)$. Colours indicate the number of individuals.

\begin{tabular}{|c|c|c|c|c|c|c|c|}
\hline Family & Species & Pont & Memp & MKtp & Samp & Mang & Samr \\
\hline Rhinidae & Rhina ancylostoma & + & & & + & & \\
\hline \multirow[t]{2}{*}{ Rhynchobatidae } & Rhynchobatus australie & +++ & & & & + & \\
\hline & Rhynchobatus sp cf. laevis & & + & & + & + & \\
\hline \multirow[t]{2}{*}{ Rhinobatidae } & Rhinobatos thouin & & & & & & + \\
\hline & Rhinobatos typus & + & & & & & + \\
\hline \multirow[t]{19}{*}{ Dasyatidae } & Taeniura lymma & & + & + & & & \\
\hline & Dasyatis kuhlii & ++ & ++ & ++ & & +++ & \\
\hline & Dasyatis zugei & + & ++ & + & t+ & & \\
\hline & Himantura chaopraya & & & & + & & \\
\hline & Himantura fai & + & & + & & & \\
\hline & Himantura fava & & & & & & + \\
\hline & Himantura gerrardi & +++ & ++ & ++ & ++ & + & $+t$ \\
\hline & Himantura sp. cf. gerrardi.(no spot) & + & & ++ & + & & \\
\hline & Himantura cf imbricata & & & + & & & \\
\hline & Himantura jenkinsii & ++ & & + & & & \\
\hline & Himantura pastinacoides & + & + & & ++ & & ++ \\
\hline & Himantura uarnak & + & + & + & + & + & + \\
\hline & Himantura uarnacoides & + & ++ & + & ++ & + & + \\
\hline & Himantura sp.cf. uarnacoides & + & ++ & & & & + \\
\hline & Himantura undulata & + & & & & & \\
\hline & Himantura walga & + & ++ & ++ & ++ & & \\
\hline & Himantura lobistoma & & ++ & & + & & + \\
\hline & Pastinachus sephen & + & + & + & & ++ & ++ \\
\hline & Pastinachus solocirostris & + & + & & + & & t+ \\
\hline \multirow[t]{2}{*}{ Gymnuridae } & Aetoplatea zonura & + & & & & + & \\
\hline & Gymnura cf. poecilura & + & ++ & ++ & ++ & & + \\
\hline \multirow[t]{6}{*}{ Myliobatidae } & Aetobatus guttatus & & & + & & & \\
\hline & Aetobatus narinari & ++ & & ++ & + & & \\
\hline & Aetomylaeus maculates & & + & + & + & + & \\
\hline & Aetomylaeus milvus & & & & & & + \\
\hline & Aetomylaeus nichofii & & + & + & & & \\
\hline & Aetomylaeus vespertilio & + & & + & + & & \\
\hline
\end{tabular}




\begin{tabular}{|c|c|c|c|c|c|c|c|}
\hline Family & Species & Pont & Memp & MKtp & Samp & Mang & Samr \\
\hline \multirow[t]{2}{*}{ Rhinopteridae } & Rhinoptera javanica & + & & & & & \\
\hline & Rhinoptera cf. neglecta & + & & & & & \\
\hline Mobulidae & Mobula japanica & + & & & & & \\
\hline \multirow[t]{2}{*}{ Hemiscyllidae } & Chiloscyllium indicum & & + & & & & \\
\hline & Chiloscyllium punctatum & + & + & + & + & & \\
\hline Stegostomatidae & Stegostoma fasciatum & ++ & & & & & \\
\hline \multirow[t]{3}{*}{ Hemigaleidae } & Hemigaleus microstoma & ++ & & + & + & + & \\
\hline & Hemipristis elongates & ++ & & & & + & \\
\hline & Paragaleus tengi & & & & & +++ & \\
\hline \multirow[t]{19}{*}{ Carcharhinidae } & Carcharhinus amblyrhynchoides & & & ++ & + & + & + \\
\hline & Carcharhinus amblyrhynchos & + & & & & ++ & \\
\hline & Carcharhinus brevipinna & + & & & & ++ & \\
\hline & Carcharhinus dussumieri & ++ & & & + & ++ & + \\
\hline & Carcharhinus falciformis & ++ & & & & + & + \\
\hline & Carcharhinus leucas & + & + & & & & \\
\hline & Carcharhinus limbatus & & & & + & + & + \\
\hline & Carcharhinus macloti & & & & & + & \\
\hline & Carcharhinus cf. obscurus & + & & & & & \\
\hline & Carcharhinus sealei & & & & & + & \\
\hline & Carcharhinus sorrah & & + & & & + & + \\
\hline & Galeocerdo cuvier & & & & & + & \\
\hline & Glyphis sp. & & & & + & & \\
\hline & Lamiopsis temmincki & + & & & + & & \\
\hline & Loxodon macrorhinus & + & & & & ++ & \\
\hline & Rhizoprionodon acutus & + & & & & ++ & \\
\hline & Rhizoprionodon oligolinx & + & & & & & \\
\hline & Scoliodon laticaudus & +++ & & & & & \\
\hline & Triaenodon obesus & + & & & & + & \\
\hline Sphyrnidae & Sphyrna lewini & + & & & & ++ & + \\
\hline
\end{tabular}

\begin{tabular}{|l|c|c|c|c|}
\hline Remarks: & \multicolumn{4}{|c|}{} \\
\hline & + & & ++ & +++ \\
\hline & $\begin{array}{c}1-10 \\
\text { indiv. }\end{array}$ & $11-100$ & $101-1000$ \\
\hline
\end{tabular}

Kalimantan Island (Borneo) such as Himantura lobistoma, H. pastinacoides, Pastinachus solocirostris (Dasyatidae) and Glyphis sp., which were recorded at several landing sites during the study. H. pastinacoides and $P$. solocirostris were quite common in Kalimantan. They were recorded at four landing sites, while Glyphis sp. and $H$. lobistoma were only recorded at one and two sites, respectively. Glyphis sp. was only found at Ujung Pandaran village, Sampit district, Central Kalimantan while H. lobistoma was recorded at Mempawah landing site (West Kalimantan) and Samarinda (East Kalimantan).

\section{Species composition between sites}

Species composition from six landing sites were compared their similarity level using the Bray-Curtis similarity index according to presenceabsence data. The Bray Curtis index of similarity analysis showed that in general the similarity levels between those fish landings were quite low. The highest similarity was between Mempawah and Muara Kintap landing site (56.4\%). Therefore, there were three main groups of fish landing sites according to their species composition at the similarity level $45 \%$ (Fig. 2). 


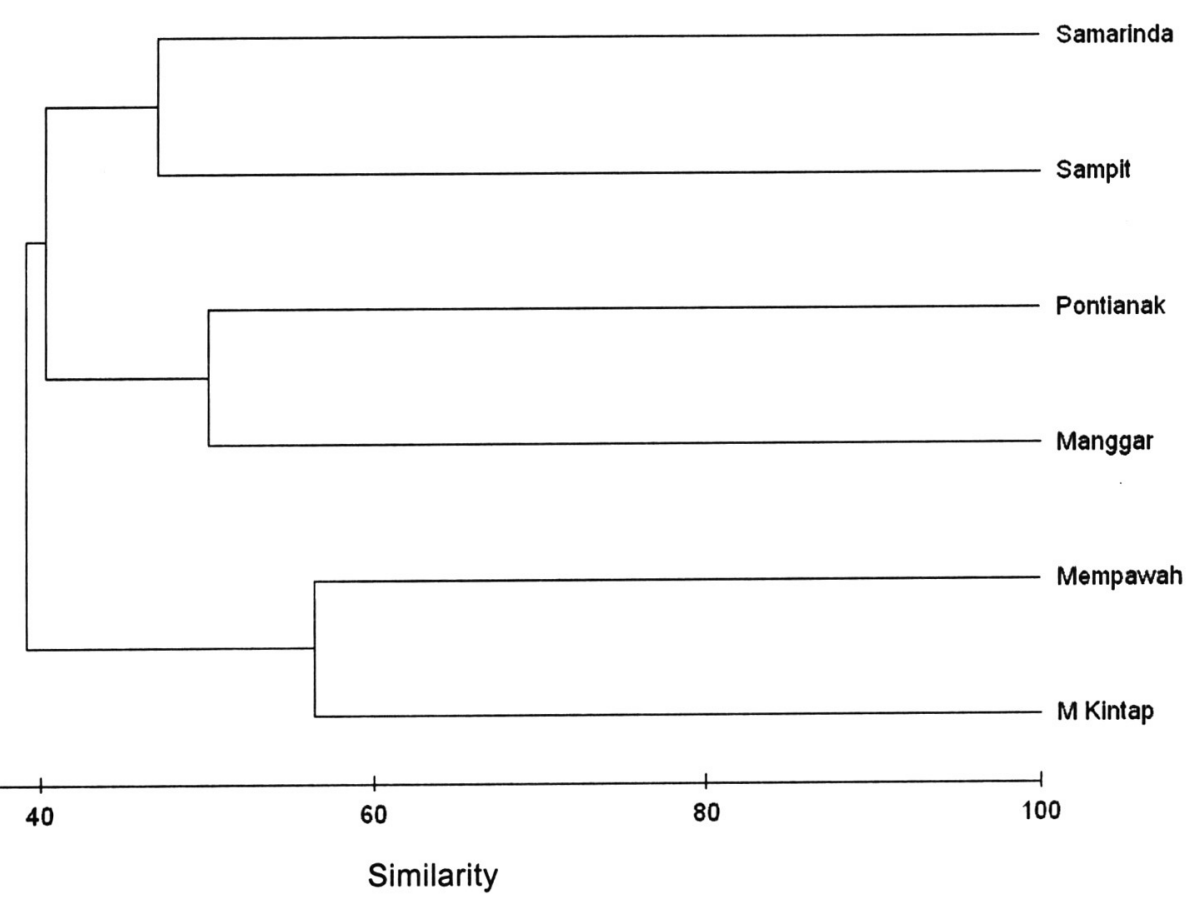

Figure 2. Dendogram based on Bray Curtis index of similarity for species composition from each landing site in Kalimantan.

Mempawah was clustered into one group with Muara Kintap, segregated from Sampit, Samarinda, Pontianak and Manggar which were seperated into two groups. The species composition per occasion were also then plotted into the two dimensional result from multidimensional scaling (MDS) ordination. The MDS plot based on the species composition at each site per occasion showed segregation of Manggar landing site from other sites (Fig. 3). The stress value of the MDS plot based on the Bray Curtis index of similarity was quite high, which was 0.22 . In general, the horizontal axis of the plot shows the separation according to the diversity of elasmobranch species recorded at each site. Manggar landing site was plotted on the left side of the ordination indicating its species composition was more different than other landing sites. In general, sharks contributed more to the species composition of landing sites that were plotted on the left side. In contrast, rays contributed more than sharks to the species composition in sites that were plotted on the left.

A one way ANOSIM using the average number of species per site was performed to test the significance of the difference in species composition among sites and showed that there were significant differences in overall species compositions ( $\mathrm{R}$ statistic $=0.81 ; p<0.005)$. Species with large differences in the average abundance and dissimilarity, contributed most to the differences among sites in the ordination plot of chondrichthyans in west central Indonesia. Chondrichthyan species which contributed significantly to the discrimination of each landing site were identified by SIMPER analysis (Table 2).

$H$. gerrardi was the most typified species in two landing sites, i.e. Pontianak (West Kalimantan) and Samarinda (East Kalimantan) with percentage contributions were $27.8 \%$ and $32.8 \%$, respectively. On the other hand, sharks species typified elasmobranch species at Manggar landing site. The percentage contributions of Carcharinus brevipinna and Paragaleus tengi were 26.4\% and $21.7 \%$, respectively.

\section{Species diversity}

Species diversity was measured by the evenness index. The index value depends on the proportion of species abundances within sites. The evenness value would be close to one if the relative abundance of each species was similar and evenness would be low if one or two species dominated in the relative abundance in a sample. 


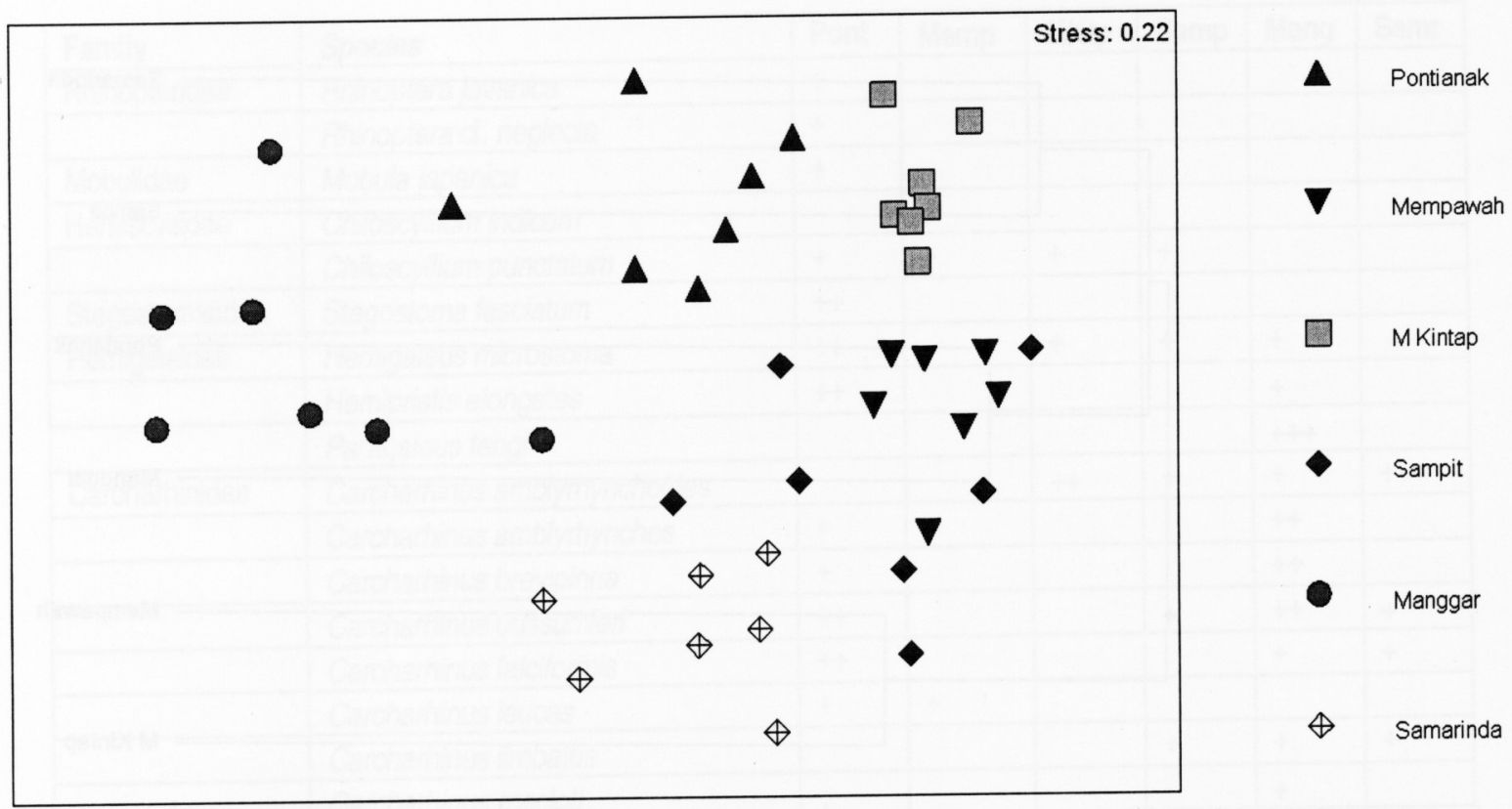

Figure 3. Two dimensional result from MDS ordination of chondrichthyan landing sites in the west central Indonesia, according to number of species in each site per occasion. Symbols correspond to landing sites.

Table 2. List of five species based on the most abundant elasmobranchs and their occurrence at six landing sites in Kalimantan.

\begin{tabular}{|l|c|r|l|c|l|}
\hline Species & Abundance & $\begin{array}{c}\% \text { of } \\
\text { abundance }\end{array}$ & Species & $\begin{array}{c}\text { Number of } \\
\text { Occurrences }\end{array}$ & $\begin{array}{c}\% \text { of } \\
\text { occurrence }\end{array}$ \\
\hline Dasyatis kuhlii & 343 & 14.85 & Himantura gerrardi & 6 & 100.00 \\
\hline Himantura gerrardi & 343 & 14.85 & Himantura uarnak & 6 & 100.00 \\
\hline Scoliodon laticaudus & 214 & 9.26 & Himantura uarnacoides & 6 & 100.00 \\
\hline Himantura walga & 187 & 8.10 & Pastinachus sephen & 5 & 83.33 \\
\hline Paragaleus tengi & 125 & 5.41 & Gymnura poecilura & 5 & 83.33 \\
\hline
\end{tabular}

Mean values of the evenness index of each site were varied between 0.39 and 0.76 (Fig. 4). The lowest evenness was recorded at Manggar (East Kalimantan) and the highest was recorded at Muara Kintap (South Kalimantan). Manggar and Muara Kintap had low standard error values due to their equality of evenness values in each occasion. In contrast, the evenness values in Pontianak landing site were varied between 0.20 and 1.00 in seven days of sampling. The evenness values equal to one in Pontianak was due to the equal number of individuals recorded on one occasion. The positions of each landing site according to their diversity indices were also similar in pattern to the evenness. Muara Kintap was more diverse than other sites and the mean species richness of this landing site was $8 \pm 1.04$ species per day. In contrast, elasmobranch diversity in Manggar landing site was the lowest and its mean species richness was only $4 \pm 1.25$ species per day (Fig. 5).

\section{DISCUSSION}

Dasyatis kuhlii was recorded as the most abundant chondrichthyan species in this study. This species was the commonest small ray in tropical Indian and western Pacific Ocean waters. $D$. kuhlii is commonly found on sandy substrates in inshore areas with depths less than $90 \mathrm{~m}$ (Compagno, 1998). Another Dasyatid found during this study was Himantura gerrardi. This species is a medium size of ray occured in the inner continental shelf and distributed widely in the Indo- 


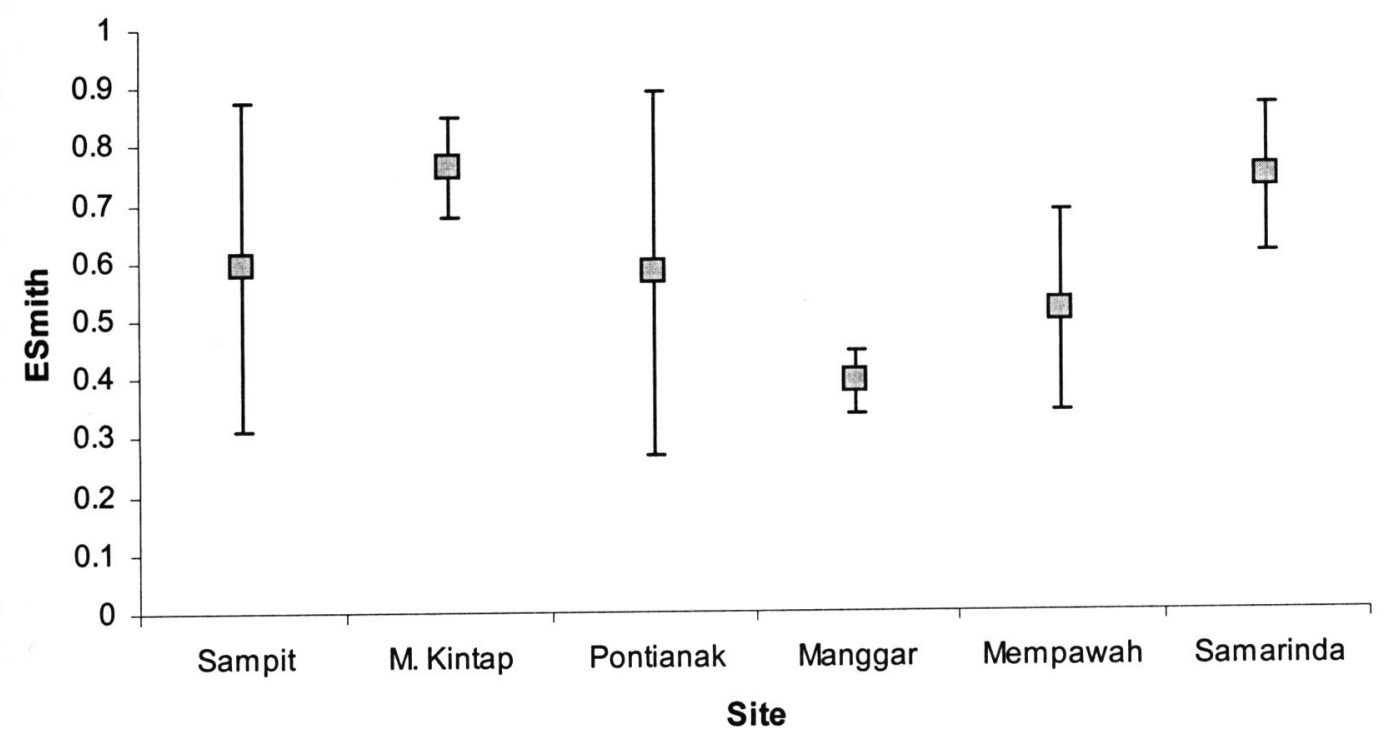

Figure 4. Mean evenness plots of chondrichthyan fishes from each landing site in Kalimantan. Error bars indicate standard deviations.

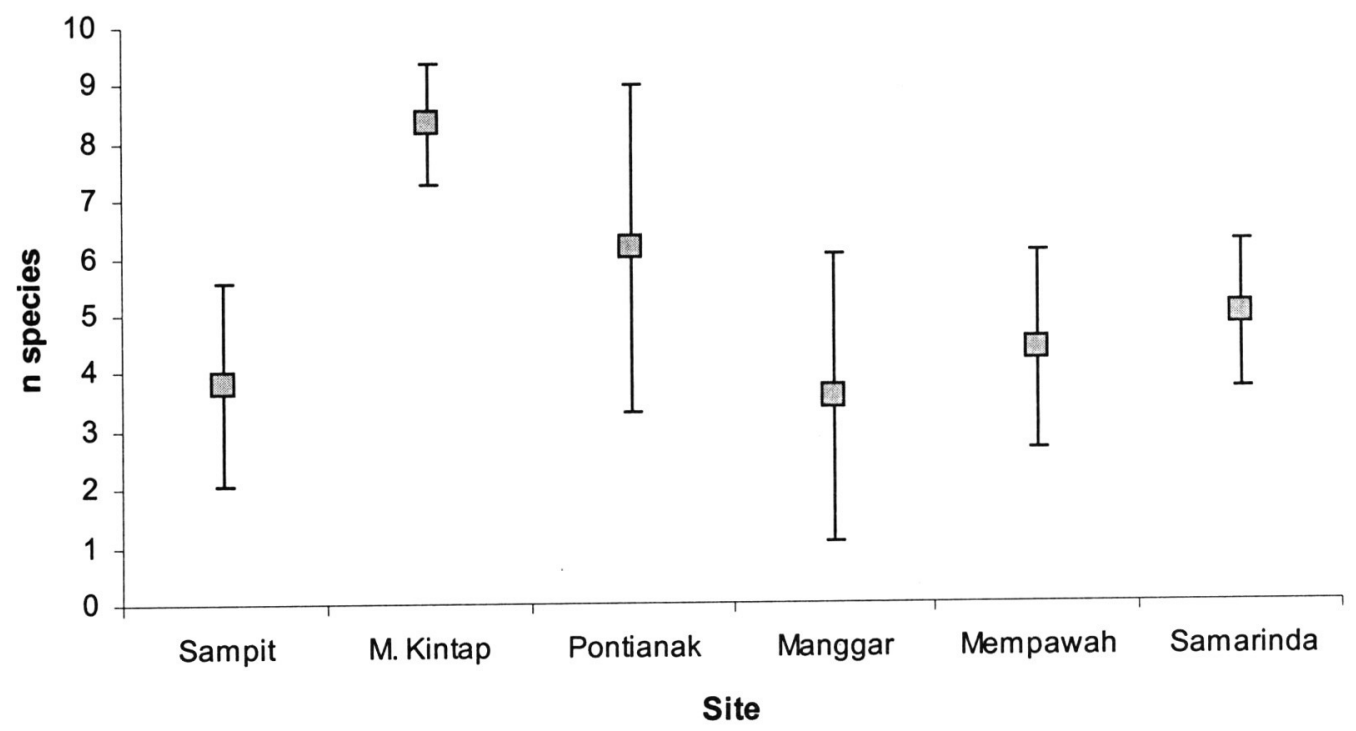

Figure 5. Mean species richness of each landing site per day in Kalimantan. Error bars indicate standard deviations

Pacific waters (Compagno, 1998). This species is also often caught in large quantities in coastal areas and muddy substrates ranging in depth from $3 \mathrm{~m}$ to $60 \mathrm{~m}$. The commonality of $H$. gerrardi recording at all landing sites in Kalimantan may due to the fishing areas of Kalimantan fishers were mainly in the coastal waters with muddy substrates and estuaries where are rich of organic materials from the river mouth. Most artisanal fishers in Kalimantan targeting demersal fishes are using the Danish seine nets and bottom longlines and are operated on soft bottom substrate in coastal areas around either their villages or small islands. The bottom substrates of Kalimantan coastal area are commonly covered by mud, especially around the river mouths and mangroves due to run off from the rivers and sedimentation process.

Some rays, such as Himantura lobistoma and Pastinachus solocilostris were two of new species described from Malaysian Borneo and seem to be restricted in the Indo-Malay region, off southwestern Borneo (Last et al., 2005; Manjaji and Last, 2006). This study presented new records on their distributions due to the discovery of these 
two species in southern and eastern Kalimantan. Another new record was Glyphis sp. that was recorded at Sampit Bay, Central Kalimantan. This species was previously recorded from Kinabatangan river, Malaysia in 1997 (Manjaji, 2002). There is a possibility that the specimen from Sampit differs from specimens from Sabah Malaysia according to the morphology but this rumor could not be proven because the Sampit specimen was not collected. Meanwhile, a new knowledge on distribution of Himantura pastinacoides was given from this study. This species was previously known from a checklist of living elasmobranchs (Compagno, 1999; Last and Compagno, 2002), and this study provides new information regarding to its distribution including western, central and eastern Kalimantan. This species is usually caught by bottom longlines in the coastal area and sandy-mud substrate (pers. obs.).

The Bray Curtis index of similarity showed a low similarity among landing sites. This was due to the heterogeneity of species composition occurred at each landing site. The various and typified fishing gears operated at each landing site and varied habitats being fished led to the differences in species composition. Thus, these factors became the main reason for the dissimilarities on species composition at each landing site. They also affected to the result of the Multidimensional scaling plot that showed a quite high stress $(0.22)$. This stress value was somewhat high with the possibility of misinterpretation. According to Clarke and Warwick (1994), a stress value less than 0.2 gives a good representation of the sample relationships with minor interpretation. The differences of species diversity among occasion in a particular landing site may lead to the high stress value of this MDS plot. For instance, there were various fishing gears were applied by fishers from Pontianak such as bottom longlines and gillnets. In a particular occasion, the gillnetters unloaded their catches with majority sharks as their catches, but on the other occasions, the species composition and diversity may be changed when the longliners unloaded their catches which mainly contained of rays.

Despite of various fishing gear types operated at each landing site, in general the elasmobranch diversity in Kalimantan was varied depending on which habitats being fished. The SIMPER analysis showed that shark species typified the species composition of the Manggar landing site. This was due to the fishing area where those sharks being caught differed from fishing area of other sites. Fishers from Manggar landing site have a fishing ground in the coastal area of East Kalimantan and in the Makassar Strait. Even though the Makassar Strait is in the enclosed water, but it has depths of $3000 \mathrm{~m}$. Therefore, some semi oceanic and continental shelf sharks were often caught by local fishers such as Carcharhinus brevipinna, $C$. falciformis and Galeocerdo cuvier. The common fishing gears operated from this landing site were gillnets and liftnets. They were operated in the Balikpapan coastal waters at depth up to $100 \mathrm{~m}$. Conversely, due to the fishing area was in the coastal waters, juveniles and immature sharks were the most common captures. Many elasmobranch species live at different habitats in their lifecycles, coastal and lagoonal waters were usually used as nursery areas for juveniles and the adults live in offshore or at deeper waters (Snelson and Williams, 1981).

The Muara Kintap landing site showed the most equitable in chondrichthyan species composition during the study. This was shown by the high mean evenness values at those sites, due to the equal number of some species recorded at that site during the study. A low diversity of chondrichthyan species at this site indicated that chondrichthyans were seldom targeted and were probably caught as bycatch. On the other hand, the high evenness values at Samarinda, was due not only to the small number of species recorded, but also the equal number of individuals per species. For instance, five species were recorded at Samarinda landing site on Day-3, but the number of individuals each species was only from one to two individuals. The high species richness at Muara Kintap indicated that the diversity of elasmobranchs in the south Kalimantan region was presumably high. However, the lower richness at other sites do not seem that species diversity at other areas were low. The lack of species diversity at several sites may also caused by other factors such as condition of landing site, target of fishery, gear types, species values, and socio economic aspects.

The occurrence of endemic and rare species in Kalimantan waters indicates that this region is still unexploited and has suitable habitats for those species. However, the degradation of 
Table 3. SIMPER result of top three species which typified each fish landing site in Kalimantan.

\begin{tabular}{|l|l|l|l|}
\hline \multicolumn{1}{|c|}{ Landing site } & \multicolumn{1}{c|}{ Species 1 } & \multicolumn{1}{c|}{ Species 2 } & \multicolumn{1}{c|}{ Species 3 } \\
\hline Muara Kintap & Himantura walga & Himantura gerrardi & Gymnura poecilura \\
\hline Sampit & Himantura uarnacoides & Himantura gerrardi & Himantura pastinacoides \\
\hline Pontianak & Himantura gerrardi & Rhynchobatus australie & Himantura uarnacoides \\
\hline Manggar & Carcharhinus brevipinna & Paragaleus tengi & Carcharhinus sorrah \\
\hline Mempawah & Himantura walga & Himantura lobistoma & Dasyatis kuhlii \\
\hline Samarinda & Himantura gerrardi & Himantura pastinacoides & Pastinachus solocirostris \\
\hline
\end{tabular}

environmental quality of the coastal area would be happened due to lots of activities along the river strains. Illegal logging, coal mining, waste water from manufactures and mangrove destructions could be the major impacted factors for the environmental degradation that can influence to the life cycle of those endemic and rare species. Therefore, management plan and conservation actions for those species should be implemented before their occurrence are threatened and their populations to be extinct.

\section{REFERENCES}

Bonfil, R. 2002. Trend and patterns in world and Asian elasmobranch fisheries. In: S. L. Fowler, T. M. Reed \& F. A. Dipper (eds.), Elasmobranch biodiversity, conservation and management: Proceeding of the international seminar and workshop in Sabah, July 1997. Gland, Switzerland and Cambridge, UK: IUCN SSC Shark Specialist Group: 15-24 pp.

Clarke, K.R., and Warwick, R.M. 1994. Change in marine communities: An approach to statistical analysis and interpretation. Plymouth Marine Laboratory, UK: $144 p$.

Clarke, K.R. 1993. Non-parametric multivatiate analyses of changes in community structure. Australian Journal of Ecology, 18, 117-143.

Compagno, L. J. V. 1998. Batoid fishes. In: K. E. Carpenter \& V. H. Niem (eds.), FAO species identification guide for fishery purposes, the living marine resources of the Western Central Pacific Rome: FAO: $1398-1529 \mathrm{pp}$.

Compagno, L. J. V. 1999. Checklist of living elasmobranchs. In: W. C. Hamlett (ed), Sharks, skates, and rays: the biology of elasmobranch fishes. Baltimore: The Johns Hopkins University Press: 471-498 pp.

Krebs, C. J. 1999. Ecological methodology (2nd ed.). An Imprint of Addison Wesley Longman, Inc., MenloPark, California: 620 pp.
Last, P. R., and Compagno, L. J. V. 2002. Review of biodiversity of rays in the South China Sea and adjacent areas. In: S. L. Fowler, T. M. Reed \& F. A. Dipper (eds.), Elasmobranch biodiversity, conservation and management: Proceeding of the International Seminar and Workshop in Sabah, July 1997. Gland, Switzerland and Cambridge, UK: IUCN SSC Shark Specialist Group: 64-69 pp.

Last, P. R., Manjaji, B. M., and Yearsley, G. K. 2005. Pastinachus solocirostris $\mathrm{sp}$. nov., a new species of stingray (Elasmobranchii: Myliobatiformes) from the Indo-Malay Archipealgo. Zootaxa, 1040, 1-16.

Manjaji, B. M. 2002. Elasmobranchs recorded from rivers and estuaries in Sabah. In: S. L. Fowler, T. M. Reed \& F. A. Dipper (eds.), Elasmobranch biodiversity, conservation and management: Proceeding of the International Seminar and Workshop in Sabah, July 1997. Gland, Switzerland and Cambridge, UK: IUCN SSC Shark Specialist Group: 194-198 pp.

Manjaji, B. M., and Last, P. R. 2006. Himantura lobistoma, a new whipray (Rajiformes: Dasyatidae) from Borneo, with comments on the status of Dasyatis microphthalmus. Ichthyological Research, 53, 290-297.

Snelson, F.F.Jr., and williams, S.E. 1981. Notes on the occurence, distribution and biology of elasmobranch fishes in the Indian River Lagoon System, Florida. Estoaries, 4, 110-120.

Stevens, J. D., Bonfil, R., Dulvy, N. K., and Walker, P. A. 2000. The effect of fishing on sharks, rays and chimaeras (chondrichthyans), and the implications for marine ecosystem. ICES Journal of Marine Science, 57, 476-494.

TRAFFIC. 2002. A CITES priorities: Sharks and the twelfth meeting of the conference of the parties to CITES. Retrieved 6 February, 2004, from http:// www.traffic.org/news/Sharks_CoP12.pdf.

White, W. T., Last, P. R., Stevens, J. D., Yearsley, G. K., Fahmi, and Dharmadi. 2006. Economically important sharks and rays of Indonesia. ACIAR, Canberra: 329 pp. 